\title{
PENERAPAN ALAT PERAGA KEPING BERWARNA UNTUK MENINGKATKAN HASIL BELAJAR PENJUMLAHAN DAN PENGURANGAN BILANGAN BULAT
}

\author{
Heri Susianto \\ Guru SDN Watukenongo 2 Kec. Pungging Kab. Mojokerto \\ Email: herisusianto61@yahoo.co.id
}

\begin{tabular}{l}
\hline Tersedia Online di \\
http://www.jurnal.unublitar.ac.id/ \\
index.php/briliant
\end{tabular}

Sejarah Artikel

Diterima pada 2 Januari 2017

Disetuji pada 20 Januari 2017

Dipublikasikan pada 1 Februari

2017 Hal. 18 - 24

\section{Kata Kunci:}

Keeping berwarna, hasil belajar, penumlahan dan pengurangan,

bilangan bulat

\begin{abstract}
Abstrak: Penelitian ini bertujuan untuk mendeskripsikan ada tidaknya pengaruh penerapan alat peraga keping berwarna terhadap peningkatan aktivitas belajar dan hasil belajar matematika materi operasi penjumlahan dan pengurangan bilangan bulat siswa kelas V SDN Watukenongo 2. Jenis penelitian yang digunakan yaitu penelitian tindakan kelas sebanyak 2 siklus. Subyek penelitian adalah siswa kelas V SDN Watukenongo 2 sebanyak 30 siswa. Instrument penelitian menggunakan lembar observasi dan lembar tes. Hasil analisis data menunjukkan bahwa dengan menerapkan media keping berwarna ternyata dapat meningkatkan aktivitas dan hasil belajar siswa. Hasil belajar yang diperoleh siswa secara klasikal mengalami peningkatan dari siklus I ke siklus II yaitu sebesar $35 \%$ dari $60 \%$ menjadi $90 \%$ dengan nilai rata-rata 65 pada siklus I meningkat menjadi 85 pada siklus II.
\end{abstract}

Dasar-dasar dari ilmu matematika ada pada sekolah dasar (SD), karena disekolah dasar dipelajari tentang penjumlahan, pengurangan, perkalian, pembagian dan materi-materi lainnya. Dasar-dasar dari ilmu matematika yang diajarkan di sekolah dasar (SD) membuat siswa banyak mengeluh akan sulitnya materi bilangan bulat terutama pada penjumlahan dan pengurangan. Kesulitan materi tersebut kemungkinan ada pada kurangnya kesadaran pendidik untuk menggunakan alat peraga yang sesuai dengan materi operasi bilangan bulat, yang seharusnya materi tersebut menggunakan alat peraga tetapi pendidik tidak menggunakan alat peraga atau menggunakan alat peraga tetapi tidak sesuai dengan materi yang diajarkan. Untuk dapat menjamin hasil belajar yang baik, maka siswa harus dihadapkan pada obyek-obyek yang dapat menarik perhatian siswa, bila tidak, maka perhatian siswa tidak akan terarah atau fokus pada obyek yang sedang dipelajarinya (Munadi,Yuhdi, 2010:27).

Sulitnya siswa dalam memahami penjumlahan dan pengurangan pada bilangan bulat juga ditemui dikelas V SDN Watukenongo 2 Kecamatan Pungging Kabupaten Mojokerto. Siswa juga kurang semangat bila mempelajari matematika dan bahkan sering mengeluh. Bukti ini didapat peneliti pada saat melaksanakan pembelajaran matematika pada kelas tersebut. Peneliti juga sebagai guru di SDN Watukenongo 2 tentu mengetahui akan masalah-masalah ini sehingga 
berkewajiban untuk mengatasinya yaitu dengan menerapkan alat peraga keping berwarna dalam pembelajaran untuk mengatasi sulitnya siswa memahami materi penjumlahan dan pengurangan. Beberapa teori yang mendukung penggunaan alat peraga pada siswa yan masih duduk di Sekolah Dasar.

Menurut Jean Piaget (dalam Nur, 1998:11), seorang anak maju melalui empat tahap perkembangan kognitif, antara lahir dan dewasa, yaitu: tahap sensorimotor, pra operasional, operasi konkrit, dan operasi formal. Usia anak 7 sampai dengan 11 tahun masih berada pada tahap konkrit (Trianto, 2007:22) yaitu usia anak SD yang masih membutuhkan alat peraga atau hal-hal yang konkrit atau nyata dalam memahami suatu hal, khususnya mata pelajaran matematika materi pokok bilangan bulat.

Jerome Bruner, seorang ahli psikologi Havard adalah salah seorang pelopor pengembangan kurikulum terutama dengan teori yang dikenal dengan pembelajaran penemuan (inkuiri). Pembelajaran penemuan (inkuiri) adalah suatu model pengajaran yang menekankan pentingnya pemahaman tentang struktur materi (ide kunci) dari suatu ilmu yang dipelajari, perlunya belajar aktif sebagai dasar dari pemahaman sebenarnya, dan nilai dari berpikir secara induktif dalam belajar (pembelajaran yang sebenarnya terjadi melalui penemuan pribadi).

Teori belajar David Ausubel Inti dari teori Ausubel tentang belajar adalah belajar bermakna. Belajar bermakna merupakan suatu proses dikaitkannya informasi baru pada konsep-konsep relevan yang terdapat dalam struktur kognitif seseorang (Dahar, 1998:137 dalam Trianto, 2007:25). Faktor yang paling penting yang mempengaruhi belajar ialah apa yang telah diketahui siswa. Berdasarkan uraian diatas, teori Ausubel sesuai dengan permasalahan yang dibahas oleh peneliti.

Berdasarkan beberapa teori di atas, maka ketika mengajar siswa kelas V materi operasi bilangan bulat, peneliti harus menanamkan konsep operasi bilangan bulat khususnya pada penjumlahan dan pengurangan, yaitu dengan cara menggunakan alat peraga keping berwarna, supaya siswa tidak hanya menghafal cara mengerjakan operasi bilangan bulat tetapi juga bisa memahami cara mengerjakan operasi bilangan bulat khususnya pada penjumlahan dan pengurangan bilangan bulat.

Alat peraga dalam mengajar memegang peranan penting sebagai alat bantu untuk menciptakan proses belajar-mengajar yang efektif. Dalam proses belajar-mengajar alat peraga dipergunakan untuk tujuan membantu guru agar proses belajar siswa lebih efektif dan efisien (Sudjana, Nana, 2010:99). Alat peraga keping berwarna adalah alat peraga yang terbuat dari bahan : tutup botol yang diberi warna merah dan warna putih. Warna merah untuk mewakili bilangan negatif dan warna putih untuk mewakili bilangan positif. Aturan penggunaan keping berwarna adalah mengikuti operasi yang ada pada bilangan. Apabila ada warna positif dan negatif jika di gabungkan, maka hasilnya sama dengan nol. 


\section{METODE}

\section{Rancangan Penelitian}

Penelitian ini merupakan Penelitian Tindakan Kelas (PTK) atau Classroom Actions Research. PTK adalah penelitian yang dilakukan oleh guru di kelasnya sendiri dengan cara merencanakan, melaksanakan, dan merefleksikan tindakan secara kolaboratif dan partisipatif dengan tujuan memperbaiki kinerjanya sebagai guru, sehingga hasil belajar siswa dapat meningkat. PTK memiliki Skema pelaksanaan penelitian (Kusumah, 2010 : 22)

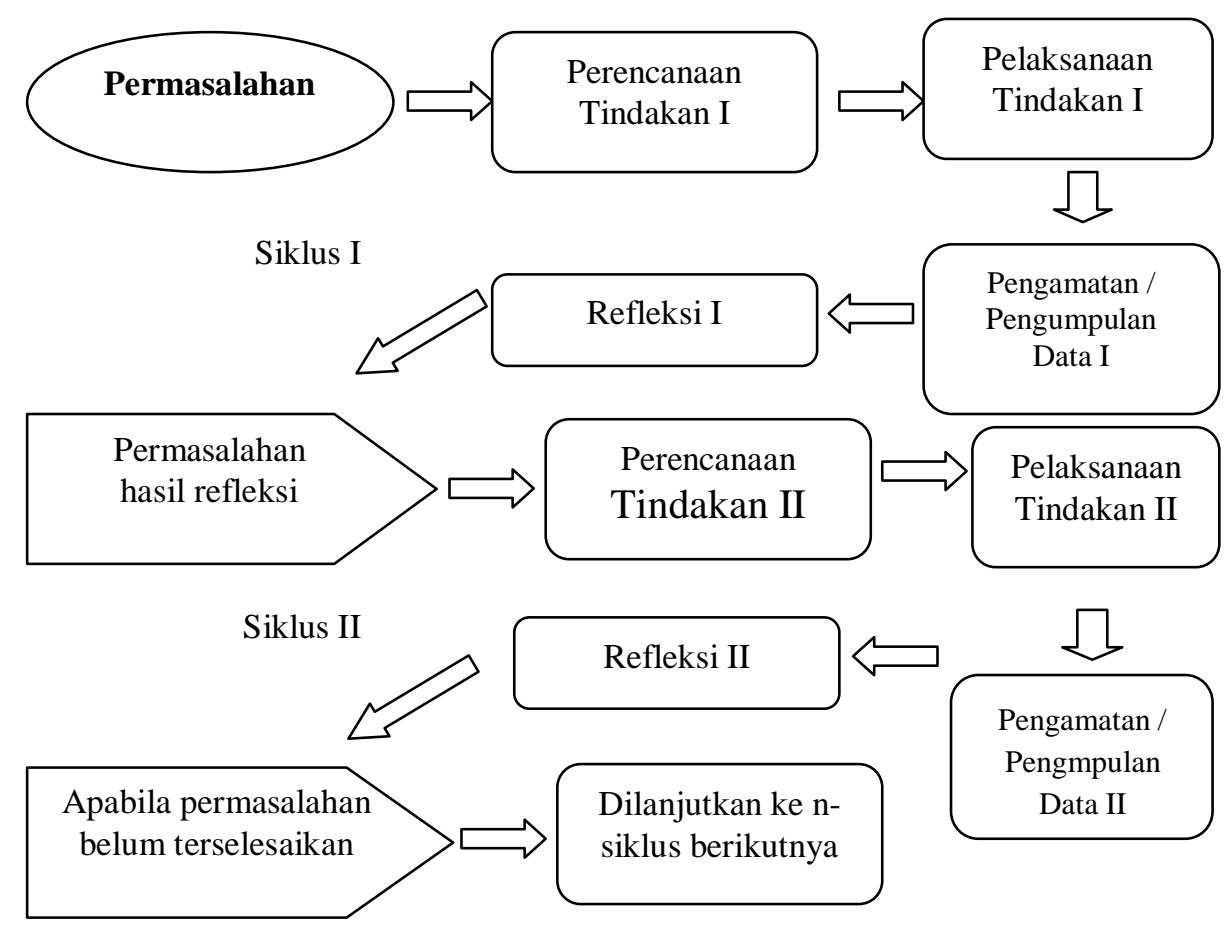

Gambar 1 Siklus PTK

\section{Subjek Penelitian}

Subjek penelitian adalah kelas V semester gasal di SDN Watukenongo 2 pada tahun ajaran 2016/2017. Jumlah siswa pada tahun ajaran ini adalah 30 siswa yang terdiri dari 14 siswa laki-laki dan 16 siswa perempuan.

\section{Waktu Penelitian}

Penelitian ini dilaksanakan selama 4 bulan yaitu mulai Juli 2016 September 2016 dengan rincian waktu sebagai berikut (1) Siklus I pertemuan 1 pada hari Selasa 12 Juli 2016, (2) Siklus I pertemuan 2 pada hari Sabtu 16 Juli 2016, (3) Siklus II pertemuan 1 pada hari Selasa 19 Juli 2016, (4) Siklus II pertemuan 2 pada hari Sabtu 23 Juli 2016. 


\section{Metode Pengumpulan Data}

Metode pengumpulan data pada penelitian ini dilakukan dengan metode pengamatan atau observasi dan metode tes. Metode observasi atau pengamatan adalah proses pengambilan data dalam penelitian dimana peneliti atau pengamat melihat situasi penelitian (Kusumah, 2011 : 66). Dalam penelitian ini, observasi dilakukan untuk melihat dan mengamati secara langsung aktivitas siswa kelas V SDN Watukenongo 2 dalam proses pembelajaran di dalam kelas.

Metode tes merupakan alat pengukur data yang berharga dalam penelitian. Tes ialah seperangkat rangsangan (stimuli) yang diberikan kepada seseorang dengan maksud untuk mendapatkan jawaban-jawaban yang dijadikan penetapan skor angka (Kusumah, 2011 : 78). Dalam penelitian ini, tes diberikan kepada siswa dengan tujuan untuk mengetahui tingkat pemahaman siswa tentang materi operasi bilangan bulat pada penjumlahan dan pengurangan.dengan media keping berwarna.

\section{Instrumen Penelitian}

Instrumen merupakan alat bantu bagi peneliti di dalam menggunakan metode pengumpulan data (Arikunto, 2009 : 101). Dalam penelitian ini, instrumen yang digunakan peneliti berupa: (a) Lembar pengamatan atau observasi ini digunakan selama proses belajar mengajar berlangsung melalui proses belajar. Instrumen ini meliputi lembar pengamatan lembar pengamatan aktivitas siswa. (b) Soal Tes. Adapun lembar tes yang digunakan adalah tes subjektif berbentuk uraian. Tes uraian adalah pertanyaan yang menuntut siswa menjawab dalam bentuk menguraikan, menjelaskan, membandingkan, memberikan alasan, dan bentuk lainnya yang sejenis sesuai dengan tuntutan pertanyaan dengan menggunakan kata-kata dan bahasa sendiri. Peneliti memberikan soal sebanyak 5 item yang berhubungan dengan materi operasi bilangan bulat.

\section{Teknik Analisis Data}

Analisis data adalah cara yang paling menentukan dalam menyusun dan mengolah data yang terkumpul sehingga dapat menghasilkan suatu kesimpulan yang dapat dipertanggungjawabkan. Adapun teknik analisis data yang digunakan adalah sebagai berikut, (1) Teknik Analisis Aktivitas Siswa. Data tentang aktivitas siswa dihitung dengan menggunakan rumus prosentase aktivitas belajar $=$ jumlah semua skor/skor masksimum x 100\%. (2) Teknik Analisis Hasil Belajar Siswa. Untuk menghitung prosentase ketuntasan belajar siswa digunakan rumus Prosentase siswa yang tuntas belajar $=$ jumlah siswa yang tuntas/jumlah siswa $\mathrm{x}$ $100 \%$.

\section{HASIL PENELITIAN \\ Siklus I \\ Perencanaan}

Tahap perencanaan tindakan pada siklus I meliputi kegiatan: (1) Membuat alat bantu pembelajaran (alat peraga keping berwarna). (2) Membuat soal tes untuk diuji validitasnya di sekolah lain, (3) Menyusun perangkat 
pembelajaran (membuat RPP), (4) Menentukan jadwal penelitian,

Mempersiapkan lembar observasi yaitu lembar aktivitas belajar siswa.

\section{Pelaksanaan Tindakan}

Pelaksanaan tindakan pada siklus I merupakan proses pembelajaran menggunakan alat peraga keping berwarna pada materi pengurangan dan penjumlahan bilangan bulat yang dilaksanakan dalam dua kali pertemuan pada hari Selasa tanggal 12 Juli 2016 dan hari Sabtu tanggal 16 Juli 2016. Dalam penelitian ini, peneliti bertindak sebagai guru secara langsung mengelola proses pembelajaran menggunakan alat peraga keping berwarna. Adapun pembelajarannya mengacu pada Rencana Pelaksanaan Pembelajaran (RPP). Diakhir pembelajaran guru memberikan soal tes siklus I untuk mengetahui tingkat keberhasilan siswa dalam pembelajaran yang telah dilakukan.

\section{Observasi}

Kegiatan observasi dilakukan oleh observer yaitu teman sejawat untuk mengetahu aktivitas siswa diobservasi dengan menggunakan instrumen berupa lembar observasi.

Dalam proses pembelajaran, rata-rata nilai aktivitas siswa pada siklus I adalah $75 \%$ yang termasuk dalam kriteria baik. Dengan demikian aktivitas belajar siswa dapat dikatakan aktif dalam mengikuti pembelajaran di kelas. Tetapi hasil ini masih belum memenuhi kreteria yang telah ditetapkan pada indikator keberhasilan Penelitian Tindakanan Kelas sehingga perlu dilanjutkan ke Siklus II.

Hasil belajar siswa pada siklus I diperoleh nilai rata-rata kelas yaitu 65 . Dari 30 siswa terdapat siswa yang tidak tuntas belajarnya yaitu ada 10 siswa sedangkan yang tuntas ada 15 siswa, ini berarti ketuntasan klasikal kelas mencapai $60 \%$.

\section{Refleksi}

Berdasarkan ketuntasan klasikal hasil belajar siswa pada siklus I yaitu 60\%, hasil observasi aktivitas siswa dan aktivitas guru dalam mengelola pembelajaran pada siklus I termasuk kriteria baik. Hasil observasi penelitian pada materi luas bangun segitiga, persegi, persegipanjang siklus I.

\section{Siklus II}

\section{Perencanaan}

Tahap perencanaan tindakan pada siklus II meliputi kegiatan yang terdiri dari: (1) Peneliti menyusun perangkat pembelajaran (membuat RPP), Soal tes, lembar observasi aktivitas siswa, aktivitas guru. (2) Peneliti menentukan jadwal penelitian.

\section{Pelaksanaan Tindakan}

Pelaksanaan tindakan pada siklus II dilaksanakan dalam dua kali pertemuan pada tanggal 19 Juli 2016 dan 23 Juli 2016. Adapun pembelajarannya mengacu pada RPP. Diakhir pembelajaran guru memberikan soal tes siklus II 
untuk mengetahui tingkat keberhasilan siswa dalam pembelajaran yang telah dilakukan.

\section{Observasi}

Dalam proses pembelajaran, rata-rata nilai aktivitas siswa pada siklus II adalah $95 \%$ termasuk dalam kriteria sangat baik. Dengan demikian hasil aktivitas belajar siswa dapat dikatakan sangat aktif dalam mengikuti pembelajaran di kelas. Hasil ini sudah memenuhi kreteria indikator keberhasilan penelitian sehingga tidak perlu dilanjutkan ke Siklus berikutnya. Perbandingan aktivitas belajar Siklus I dan Siklus II peneliti sajikan pada gambar 1

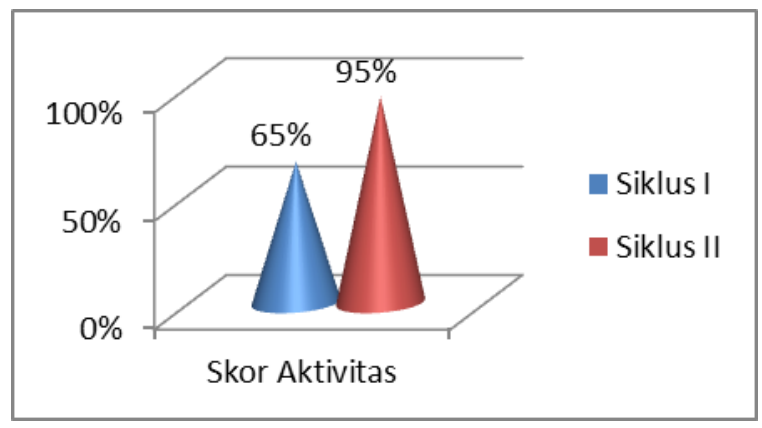

Gambar .1 Perbandingan Aktivitas Belajar Siklus I dan II

Hasil belajar siswa pada siklus II diperoleh nilai rata-rata kelas yaitu sebesar 85. Dari 30 siswa terdapat 3 siswa yang tidak tuntas belajarnya karena nilai yang didapat belum mencapai KKM, sedangkan yang tuntas ada 27 siswa, ini berarti mencapai ketuntasan klasikal 90\%.

\section{Ketuntasan Klasikal Hasil Belajar Siswa}

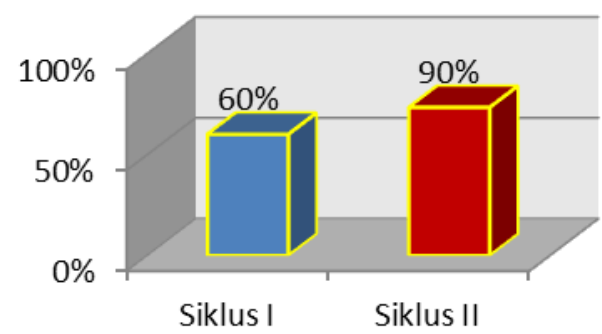

Gambar 2 Hasil Belajar Siswa Siklus I dan Siklus II

\section{Refleksi}

Pada tahap ini akan dijelaskan apa yang telah terlaksana dengan baik dalam proses pembelajaran dengan mengunakan alat peraga keping berwarna pada materi pengurangan dan penjumlahan bilangan bulat. Hasil analisis data menunjukkan pada aktivitas belajar maupun hasil belajar telah mengalami peningkatan dengan baik dari siklus I ke siklus II.

Dari semua aspek yang diamati, tampak bahwa proses pembelajaran yang dilaksanakan secara umum sudah mengalami perbaikan dan peningkatan. Bisa 
dikatakan sebagian besar siswa sudah sangat aktif mengikuti pembelajaran sehingga aktivitas siswa dikatakan sangat baik dalam mengikuti pembelajaran sudah bisa diperbaiki kekurangan pada siklus I, sehingga pada tindakan siklus II ini dirasa cukup maka tidak perlu langkah perbaikan pada siklus berikutnya

\section{KESIMPULAN}

Berdasarkan hasil penelitian dan pembahasan yang telah diuraikan dapat disimpulkan sebagai berikut: (1) Hasil analisis Aktivitas siswa secara keseluruhan mengalami peningkatan dari siklus I ke siklus II. Hal ini tampak pada proses pembelajaran secara umum rata-rata nilai yang diperoleh siswa meningkat dari $65 \%$ menjadi $95 \%$. Sehingga dapat disimpulkan bahwa penggunaan alat peraga keping berwarna meningkatkan aktivitas belajar siswa. (2) Hasil belajar yang diperoleh siswa, tampak secara klasikal bahwa ketuntasan belajar siswa mengalami peningkatan dari siklus I ke siklus II yaitu sebesar 30\% dari $60 \%$ menjadi 90\%. Nilai rata-rata hasil belajar pada siklus I sebesar 65 sedangkan pada siklus II sebesar 85. Oleh karena ketuntasan nilai secara klasikal sudah mencapai batas yang telah ditentukan yaitu lebih dari $\geq 70 \%$, maka dapat disimpulkan bahwa penggunaan alat peraga keping berwarna dapat meningkatkan hasil belajar siswa.

\section{SARAN}

Beberapa saran yang dapat diberikan peneliti, yaitu sebagai berikut : (1) Untuk mengubah anggapan siswa mengenai pelajaran matematika yang mereka anggap susah dan menakutkan, sebaiknya guru menentukan metode atau alat peraga yang menarik, efisien, efektif, dan tepat guna misalnya saja keping berwarna. (2) Pada penggunakan alat peraga keping berwarna hendaknya guru memahami dengan baik penggunaan alat peraga tersebut, sehingga pada saat proses pembelajaran tercipta suasana belajar yang menyenangkan, mengurangi kejenuhan dalam diri siswa. (3) Pada saat proses pembelajaran, guru sebaiknya melibatkan siswa secara aktif misalnya dengan melakukan demonstrasi dan mengerjakan soal-soal latihan agar pembelajaran bermakna.

\section{DAFTAR RUJUKAN}

Arikunto, Suharsimi. 2009. Manajemen Penelitian. Rineka Cipta : Jakarta

Kusumah, Wijaya dan Dwitagama, Dedi. 2011. Mengenal Penelitian Tindakan Kelas. PT Indeks : Jakarta

Sudjana, Nana. 2010. Dasar-Dasar Proses Belajar Mengajar. Sinar Baru Algesindo : Bandung

Sudjana, Nana dan Ibrahim. 2010. Penelitian dan Penilaian Pendidikan. Sinar Baru Algesindo : Bandung

Sukardi. 2011. Metodologi Penelitian Pendidikan. PT Bumi Aksara : Jakarta 